\title{
ANALISIS HARD SKILL SEBAGAI PONDASI BISNIS BAGI PELAKU USAHA MIKRO
}

\section{Kamaludin}

Akademi Maritim Cirebon (AMC)

Email: kamaludin.abahrizka@gmail.com

\section{Abstract}

This study aims to obtain an overview of the understanding of micro business actors on the importance of hard skills in maintaining the existence of their businesses and obtaining in-depth studies related to the development of the implementation of hard skills owned by micro businesses in order to improve the quality of their business management. This study uses qualitative research methods based on the objectives and issues studied with the focus of research in research that is analyzing hard skills as a basic foundation in maintaining the existence of its business and developing the implementation of hard skill competencies in order to improve the quality of business management it runs. Data collection techniques used in this study were observation techniques, interview techniques, and documentation techniques. The results of this study are in the form of a hypothesis that hard skills have an influence on the system of micro business activities, hard skills are the basic foundation for micro businesses in maintaining the existence of business activities, and the hard skills of micro businesses can be improved through basic management training.

Keyword: Hard Skill, Business Foundation, Micro Business Actors

\begin{abstract}
Abstrak
Penelitian ini bertujuan untuk memperoleh gambaran terhadap pemahaman pelaku usaha mikro akan pentingnya hard skill dalam menjaga eksistensi usahanya serta memperoleh kajian mendalam berkaitan dengan pengembangan implementasi hard skill yang dimiliki oleh pelaku usaha mikro dalam rangka peningkatan kualitas manajemen usaha yang dimiliki. Penelitian ini menggunakan metode penelitian kualitatif berdasarkan tujuan dan permasalahan yang diteliti dengan fokus penelitian dalam penelitian yaitu menganalisa hard skill sebagai pondasi dasar dalam menjaga eksistensi usahanya dan pengembangan implementasi kompetensi hard skill dalam rangka peningkatan kualitas manajemen usaha yang dijalankanya. Teknik pengumpulan data yang digunakan dalam penelitian ini adalah teknik observasi, teknik wawancara, dan teknik dokumentasi. Hasil penelitian ini berupa hipotesis bahwa hard skill memiliki pengaruh terhadap sistem kegiatan usaha mikro, hard skill merupakan pondasi dasar bagi pelaku usaha mikro dalam menjaga eksistensi kegiatan usaha, serta hard skill pelaku usaha mikro dapat ditingkatkan melalui pelatihan dasar manajemen.
\end{abstract}

Kata kunci: Hard Skill, Pondasi Bisnis, Pelaku Usaha Mikro 


\section{Pendahuluan}

Usaha Kecil Menengah atau yang biasa disebut UKM adalah salah satu roda perekonomian rakyat yang harusnya berjalan dan dapat menumpu perekonomian dalam pelaksanaannya (Siagian, dkk. 2019). Usaha mikro memiliki peran strategis dalam kegiatan mikro ekonomi di Indonesia. Hal ini menunjukan bahwa usaha mikro merupakan salah satu penopang kegiatan ekonomi masyarakat yang penting di Indonesia. Menurut data Kementerian Koperasi dan UKM RI melaporkan bahwa secara jumlah unit, UMKM memiliki pangsa sekitar 99,99\% (62,9 juta unit) dari total keseluruhan pelaku usaha di Indonesia (2017), sementara usaha besar hanya sebanyak 0,01\% atau sekitar 5400 unit. Usaha Mikro menyerap sekitar 107,2 juta tenaga kerja (89,2\%), Usaha Kecil 5,7 juta (4,74\%), dan Usaha Menengah 3,73 juta (3,11\%); sementara Usaha Besar menyerap sekitar 3,58 juta jiwa. Artinya secara gabungan UMKM menyerap sekitar 97\% tenaga kerja nasional, sementara Usaha Besar hanya menyerap sekitar 3\% dari total tenaga kerja nasional (Hidayah, dkk. 2018). Selain itu pula, usaha mikro memiliki peran stategis karena usaha mikro merupakan sebuah alternative usaha ketika sempitnya peluang kerja yang tersedia di perusahaan serta menjadi alternative ketika modal yang dimiliki dalam jumlah yang terbatas.

Namun demikian, ketika sebuah kegiatan usaha dihadapkan pada sebuah alternative usaha maka harus dikelola dengan sebaik mungkin agar kegiatan usaha dapat bertahan dalam persaingan usaha yang ketat saat ini dan dapat berkembang secara berkelanjutan. Kaitanya terhadap hal ini, fokus usaha yang dikerjakan harus memiliki konsep yang baik. Hal ini dimaksudkan agar peluang usaha yang diciptakan bukan sesuatu kegiatan usaha yang temporer atau dengan kata lain hanya ikut-ikutan kegiatan usaha yang lagi trend serta tidak dikerjakan dengan prinsip keuletan. Penting rasanya pelaku usaha mikro memiliki konsep yang baik jika akan membangun sebuah kegiatan usaha mikro. Melalui konsep yang baik ini, Pelaku usaha mikro dapat mengkaji produk apa yang akan dijual, pasar mana yang akan dituju, berapa harga produk yang akan dijual, serta apakah produk yang dijual akan laku di pasaran.

Modal yang terbatas yang dimiliki pelaku usaha mikro harus dapat dikelola dengan baik. Hal ini dimaksudkan agar usaha yang dijalankan dapat menghasilkan keuntungan, kegiatan usaha dapat terus melakukan kegiatan operasionalnya dan tidak mengkikis modal yang ada. Terbatasnya modal menjadikan pelaku usaha mikro harus bertindak secara efektif Berkaitan dengan hal ini, pelaku usaha mikro harus mampu melakukan tindakan-tindakan yang dapat memajukan kegiatan usahanya seperti menjual produk yang benar-benar diminati masyarakat dengan kualitas produk yang baik serta menjual produk dengan harga yang bersaing. Ketika produk yang dijual ini laku dipasaran, maka modal yang terbatas yang dimiliki pelaku usaha mikro memiliki tingkat perputaran modal (cash flow) yang baik.

Hal ini menjadi penting karena perputaran modal merupakan faktor mendasar dari keberlangsungan kegiatan usaha yang dijalankan oleh pelaku usaha mikro atau dengan kata lain konsep perputaran modal ini sebagai bentuk pengembalian biaya 
produksi dan keuntungan yang diperoleh. Jika perputaran modal ini tidak baik atau tidak sehat maka modal yang tersedia akan terkikis habis secara bertahap karena kerugaian yang disebakan produk yang dihasilkan tidak laku di pasaran. Mengingat terbatasnya modal yang dimiliki pelaku usaha mikro, dalam waktu singkat kerugian yang diderita oleh pelaku usaha mikro menjadikan kegiatan usaha yang dijalankan sangat rentan menjadi terhenti.

Usaha mikro merupakan kegiatan usaha yang masuk dalam sektor ekonomi informal. Sektor ini merupakan kegiatan usaha yang dilakukan dalam rangka untuk pemenuhan kebutuhan dasar bagi pelaku usahanya yang sifatnya legal, walaupun usaha mikro ini tidak membayar pajak serta tidak mengikuti perundang-undangan tenaga kerja yang berlaku. Dalam kegiatan usaha mikro, modal yang digunakan sebagai bentuk investasi merupakan modal yang mati. Hal ini karena modal yang digunakan tidak dapat digunakan sebagai jaminan di bank maupun jaminan terhadap kegiatan kerjasama yang lain. Perlu dipahami bahwa sektor informal ini memiliki tingkat kinerja yang tinggi dari para pelakunya, hal ini karena usaha mikro merupakan kegiatan dalam sektor ekonomi informal yang dasar kegiatan operasionalnya adalah beriorientasi kompetensi bagi pelaku usahanya.

Berdasarkan data penelitian RAND, think-tank sektor kebijakan global dari Amerika Serikat, menyimpulkan bahwa meskipun UMKM di Indonesia memiliki kontribusi besar terhadap perekonomian namun jenis pekerjaan yang dihasilkan biasanya memiliki tingkat upah yang murah dan relatif kurang produktif. Pekerjaan UMKM juga identik dengan pekerja yang memiliki tingkat pendidikan yang rendah sehingga tidak bisa berkembang ((ALMI), 2019). Menyikapi hal itu, perlu adanya pemahaman mendasar berkaitan dengan hard skill yang berhubungan dengan pengetahuan yang dimiliki dalam pengelolaan sebuah kegiatan usaha, kemampuan menggunakan strategi pemasaran yang baik, kemampuan dalam mengelola arus kas maupun modal, kemampuan dalam pengelolaan bahan baku, serta kemampuan dalam pengembangan usaha. Kemampuan-kemampuan itu mutlak harus dimiliki oleh pelaku usaha mikro mengingat kegiatan usaha mikro sangat rentan terjadi kebangkrutan dalam waktu yang singkat karena modal yang digunakan merupakan modal dengan skala kecil dan terbatas, jika dalam waktu satu minggu saja terjadi kerugian terus menerus maka kegiatan usahanya terhenti atau mengalami kebangkrutan. Dalam pelaksanaan kegiatan usaha mikro saat ini, hard skill belum diperhatikan oleh pelaku usaha mikro dalam menjalankan roda kegiatan usahanya. Hal ini sesungguhnya menjadi sebuah anomali antara ekistensi usaha yang harus dijalankan dengan implementasi dilapangan yang dilakukan. Kurangnya pemahaman pelaku usaha mikro akan pentingnya hard skill dalam menjaga eksistensi usahanya serta kurangnya pengembangan imlplementasi hard skill yang dimiliki oleh pelaku usaha mikro dalam rangka peningkatan kualitas manajemen usaha yang dimiliki merupakan permasalahan yang akan dikaji dalam penelitian ini.

Penelitian ini bertujuan untuk memperoleh gambaran terhadap pemahaman pelaku usaha mikro akan pentingnya hard skill dalam menjaga eksistensi usahanya serta 
memperoleh kajian mendalam berkaitan dengan pengembangan implementasi hard skill yang dimiliki oleh pelaku usaha mikro dalam rangka peningkatan kualitas manajemen usaha yang dimiliki. Dalam memecahkan permasalahan yang ada, pemanfaatan sosialisasi, seminar dan pelatihan menjadi solusi dalam peningkatan kompetensi hard skill bagi pelaku usaha mikro.

\section{Metode Penelitian}

Penelitian ini menggunakan metode penelitian kualitatif berdasarkan tujuan dan permasalahan yang diteliti. Menurut Best (Sukardi, 2005), pendekatan kualitatif adalah metode penelitian yang berusaha menggambarkan dan menginterpretasikan objek sesuai dengan apa adanya. Penelitian ini dilaksanakan selama 1 bulan yaitu pada tanggal 20 Maret sampai degan tanggal 19 April 2020, dengan tempat penelitian di Kabupaten Brebes Provinsi Jawa Tengah. Fokus penelitian dalam penelitian ini adalah menganalisa hard skill sebagai pondasi dasar dalam menjaga eksistensi usaha dan pengembangan implementasi kompetensi hard skill dalam rangka peningkatan kualitas manajemen usaha yang dijalankan pelaku usaha mikro.

Data yang diperoleh dalam penelitian ini berupa data primer dan data sekunder yang menggunakan teknik pengumpulan data dengan tekhnik Triangulasi menggunakan wawancara, Observasi, dan studi kepustakaan. Data primer diperoleh melalui wawancara dan observasi, sedangkan data sekunder diperoleh melalui studi kepustakaan. Instrument penelitian dalam penelitian ini adalah peneliti itu sendiri. Menurut (Sugiyono, 2009) peneliti sebagai instrumen penelitian, dimana peneliti berfungsi menetapkan fokus penelitian, memilih informan sebagai sumber data,melakukan pengumpulan data, menilai kualitas data, analisis data, menafsirkan data, dan membuat kesimpulan atas temuanya.

Pengambilan data dalam penelitian ini dengan cara snowball sampling yaitu informan kunci akan menunjuk orang-orang yang mengetahui masalah yang akan diteliti untuk melengkapi keterangannya dan orang-orang yang ditunjuk akan menunjuk orang lain bila keterangan kurang memadai begitu seterusnya (Mantja, 2003). Informan dalam penelitian ini adalah pelaku usaha mikro beserta konsumennya yang ada di Kabupaten Brebes sejumlah 35 orang. Teknik penganalisaan data yang digunakan yaitu dengan menganalisis data, menginterpretasi data, serta menarik kesimpulan.

\section{Hasil dan Pembahasan}

Hard skill adalah kompetensi yang berkaitan dengan kemampuan seseorang yang bersifat teknis seperti kemampuan tetang ilmu pengetahuan, pemecahan masalah, strategi yang digunakan, serta pengelolaan sesuatu hal agar berjalan efektive dan efisien. Menurut (Hendriana, Rohaeti, \& Sumarmo, 2017), Hard skill merupakan penguasaan ilmu pengetahuan, teknolgi, dan ketrampilan teknis dalam bidang tertentu yang berhubungan dengan suatu proses, alat, atau teknik. Menurut (Rasid, Tewal, \& Kojo, 2018) mendefinisikan hard skill merupakan penguasaan kemampuan teknis dari hasil pembelajaran yang berhubungan dengan suatu bidang ilmu tertentu. Sedangkan 
menurut (Thoha, 2008) Hard skill merupakan kompetensi yang didefinisikan sebagai gambaran tentang apa yang harus diketahui atau dilakukan seseorang agar dapat melaksanakan pekerjaan dengan baik.

Hard skill merupakan kompetensi dasar yang harus dimiliki oleh pelaku usaha mikro. Hal ini karena melalui hard skill konsep dari sebuah bisnis dapat dirancang dengan orientasi yang rasional dan menjadi dasar pengambilan keputusan tentang srategi pengelolaan yang akan digunakan serta melakukan evaluasi terhadap kegiatan usaha yang dilakukan. Perancangan tujuan menjadi langkah awal bagi pelaku usaha mikro untuk dapat menentukan arah dan tujuan kegiatan usaha yang di jalankan. Konsep yang jelas tentang orientasi/tujuan kegiatan usaha menjadi penting karena dalam hal ini penentuan jenis produk yang akan dijual, harga yang akan ditetapkan, serta pasar mana yang hendak dijangkau memerlukan konsep yang jelas. Perlu ada perbaikan-perbaikan mendasar tentang pemahaman rancangan konsep tujuan kegiatan yang akan dilakukan. Hal ini dirasa penting karena pelaku usaha mikro dihadapkan dengan modal yang terbatas namun dituntut agar produk yang dihasilkan dapat laku dipasaran. Dua hal tersebut menjadi sebuah dilematis tersendiri bagi pelaku usaha mikro jika hanya dilakukan dengan niatan hanya mencoba-coba melakukan sebuah kegiatan usaha, perlu ada keseriusan dalam hal ini agar kegiatan usaha dapat berjalan sebagai mana mestinya dan mendapatkan keuntungan yang diharapkan.

Pertimbangan berikutnya yang perlu dipahami oleh pelaku usaha mikro adalah orinetasi/tujuan kegiatan usaha yang rasional, artinya disini bahwa orientasi kegiatan usaha berada dalam batasan-batasan yang dapat dijangkau oleh kemampuan dari pelaku usaha mikro itu sendiri. Seperti halnya kemampuan menghasilkan produk maupun variasinya, harga yang dijual ke konsumen merupakan harga yang dapat bersaing dengan kompetitor dalam segmentasi pasar yang sama, keuntungan yang akan diambil tidak berlebihan, serta promosi yang digunakan dengan pertimbangan biaya yang terjangkau.

Strategi pengelolaan kegiatan usaha bagi pelaku usaha mikro dapat efektive serta efisien melalui hard skill yang dimiliki. Stategi pengelolaan kegiatan usaha dapat efektive dengan menggunakan cara yang tepat guna. Artinya bahwa kegiatan usaha yang dilakukan melalui mekanisme teknologi sederhana yang mudah di aplikasikan dan pengelolaan kegiatan usaha memudahkan pelaku usaha mikro dalam mengatur tata kelola bahan baku, penciptaan produk,serta variasi terhadap produk. Sedangkan strategi pengelolaan kegiatan usaha yang efisien dengan melakukan tindakan yang terkait dengan penghematan biaya. Artinya bahwa kegiatan usaha yang dilakukan oleh pelaku usaha mikro dilakukan melalui pertimbangan-pertimbangan yang didasarkan atas perimbangan manfaat yang akan didapatkan dengan biaya yang akan dikeluarkan. Seperti halnya dalam penggunaan jumlah alat produksi dengan jumlah penjualan produk setiap harinya, pembelian bahan baku dengan harga terjangkau namun memiliki kualitas yang baik, serta pengelolaan arus kas yang baik agar tidak tercampur antara kas yang digunakan untuk modal usaha dengan kas yang digunakan untuk pemenuhan kebutuhan rumah tangga. 
Berkaitan dengan hal itu, hard skill dibutuhkan oleh pelaku usaha mikro dalam melakukan evaluasi kegiatan usaha yang dilakukan. Hal ini penting karena ketepatan terhadap hasil evaluasi memiliki pengaruh terhadap perbaikan-perbaikan secara mendasar dalam konsep ketatalaksanaan kegiatan usaha mikro mulai dari perencanaan, pelaksanaan sampai ke tahap feedback yang diberikan oleh konsumen. Dalam hal ini, evaluasi dapat dipertajam dengan melakukan survey pasar terhadap produk yang telah dipasarkan sehingga hal ini akan menjadikan rujukan yang valid bagi pelaku usaha mikro dalam melakukan evaluasi kegiatan usaha. Evaluasi memiliki dua konsep dasar yang harus dipahami dengan baik oleh pelaku usaha mikro. Konsep yang pertama yaitu evaluasi ketika produk tidak laku dipasaran, berkaitan dengan hal ini maka tindakan apa yang perlu dilakukan oleh pelaku usaha mikro sebagai upaya dalam memperbaiki kualitas produk serta memperoleh kepercayaan di pasar. Hal ini dapat di implementasikan dengan perbaikan dari sisi produk baik mengenai rasa, bentuk, kemasan, ataupun jaminan kebersihan. Perbaikan juga dapat pula dilihat dari segi harga, apakah harga memiliki daya saing atau tidak serta dilihat kesesuaian antara tingkat harga dengan kualitas maupun tingkat harga dengan taraf kemampuan dari target pasar.

Konsep yang kedua yaitu evaluasi ketika produk laku di pasaran. Produk yang laku dipasaran tetap harus dilakukan evaluasi, hal ini karena produk yang laku dipasaran harus dapat ditingkatkan kualitasnya supaya tetap mampu menjadi pemimpin pasar dalam persaingan di segmentasi pasar yang sama. Evaluasi ini dapat dilakukan dalam rangka melakukan pengembangan produk agar memiliki banyak varian produk sebagai alternative pilihan bagi konsumen. Evaluasi ini juga dapat dilakukan sebagai bagian refleksi diri bagi pelaku usaha mikro agar tidak terlena terhadap apa yang telah dicapai, hal ini dirasa penting karena dalam kegiatan usaha di era sekarang persaingan yang ada begitu ketat sehingga dibutuhkan kemampuan yang lebih dalam menghadapi persaingan agar kegiatan usaha dapat bertahan, tetap ada, dan berkembang. Menurut Suchman (Arikunto, 2010), evaluasi merupakan sebuah proses menentukan hasil yang telah dicapai beberapa kegiatan yang direncanakan untuk mendukung tercapainya tujuan. Menurut (Sax, 1980) mendefinisikan evaluasi adalah proses yang melalui penilaian atau keputusan yang dibuat dari berbagai pengamatan dan latar belakang penilai. Sedangkan menurut (Sukardi, 2009), evaluasi adalah sebuah proses yang menentukan sejauh mana tujuan telah dicapai.

Perlu kita pahami bersama ada beberapa hal yang perlu kita kaji mendalam berkaitan dengan konsep hard skill yang perlu dimiliki oleh pelaku usaha mikro sebagai suatu podasi dasar terhadap kegiatan usaha yang dijalankan. Hard skill yang berupa keahlian merupakan pondasi dasar dalam tata kelola sistem pengelolaan kegiatan usaha. Hard skill juga harus dimiliki oleh pelaku usaha mikro sebagai sumber daya manusia dalam pelaksanaan kegiatan usahanya. Seperti yang dapat dijabarkan dalam bagan konsep dibawah ini : 


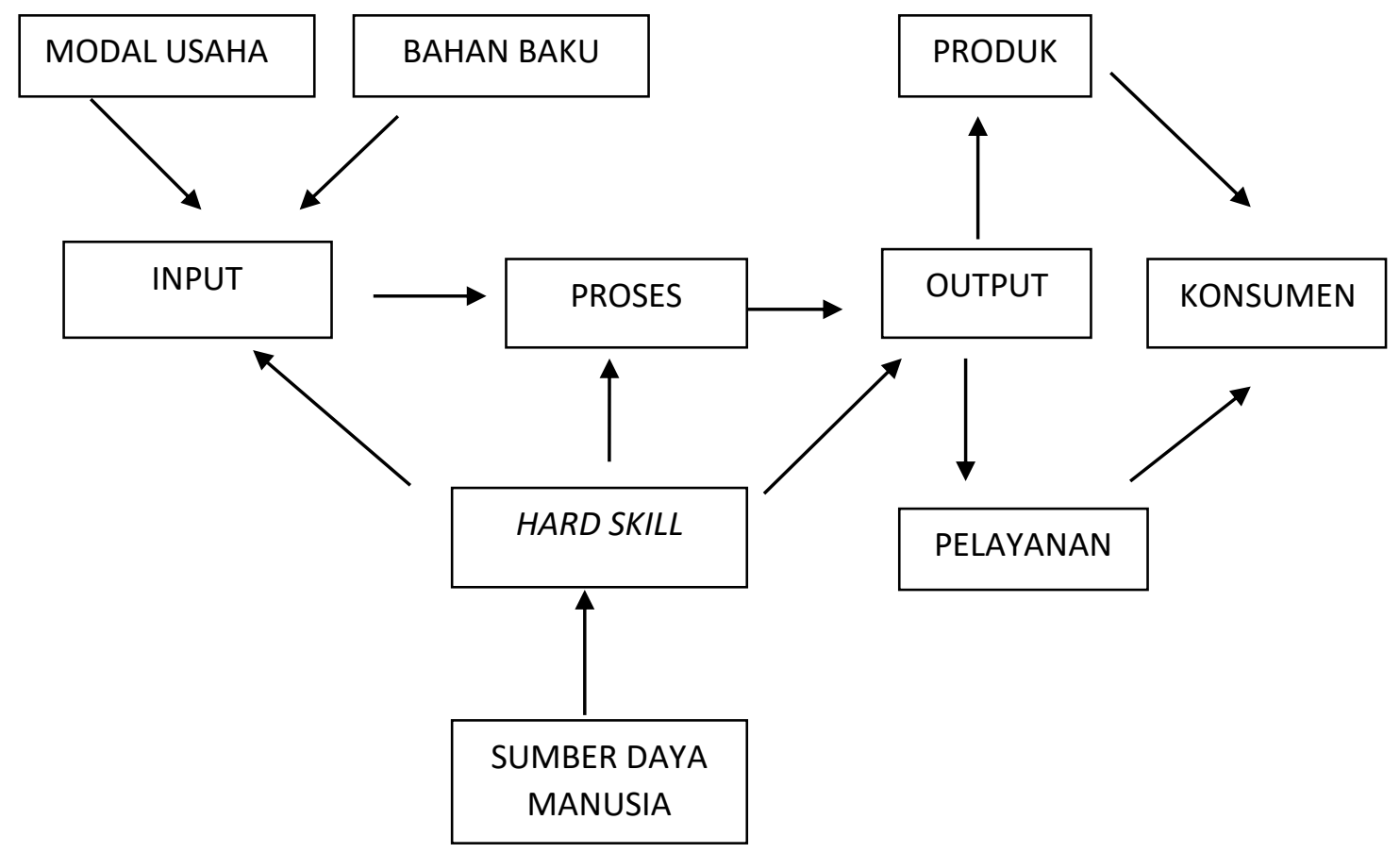

\section{Gambar 1 konsep tata kelola usaha mikro}

Dari bagan konsep di atas dapat dijelaskan bahwa sistem pengelolaan kegiatan usaha mikro meliputi komponen input, proses, dan output. Komponen input dipengaruhi oleh modal usaha yang dimiliki, ketersediaan bahan baku, serta sumber daya manusia melalui hard skill. Dalam komponen proses dipengaruhi oleh sumber daya manusia melalui hard skill. Kemudian komponen output juga dipengaruhi oleh sumber daya manusia melalui hard skill yang akan menghasilkan sebuah produk dan pelayanan yang akan diberikan kepada konsumen. Dari ketiga komponen sistem pengelolaan modal usaha mikro tersebut, faktor sumber daya manusia melalui hard skill mempengaruhi ketiga kompenen sistem pengelolaan kegiatan usaha mikro.

Dalam sistem pengelolaan kegiatan usaha mikro, komponen yang pertama yaitu input. Dalam komponen input ini unsur modal usaha, ketersediaan bahan baku, dan sumber daya manusia menjadi faktor penting. Modal usaha merupakan roh dari kegiatan usaha yang akan dijalankan pelaku usaha mikro, tanpa modal usaha akan sangat sulit pelaku usaha mikro dapat memulai serta menggerakan roda usaha. Disamping modal usaha, ketersediaan bahan baku merupakan unsur yang mempengaruhi dalam komponen input ini, melalui bahan baku baik bahan baku utama, bahan pembantu, maupun bahan komplementer harus memiliki ketersediaan yang cukup. Hal ini karena dengan tersedianya bahan baku maka kegiatan produksi dapat berjalan dengan baik dan lancar. Bahan baku merupakan cikal bakal terbentuknya sebuah produk. Keberadaan modal usaha dan bahan baku tidak akan berarti apa-apa jika tidak dirancang dan dikelola dengan baik oleh sumber daya manusia yang memiliki hard skill yang baik dalam upaya penggunaan modal usaha dengan seefisien mungkin dan pengelolaan bahan baku sebagai bahan produksi yang dimulai dari pemilihan bahan baku dengan harga yang terjangkau namun memiliki kualitas yang baik. 
Komponen yang kedua adalah proses, dalam komponen ini hal-hal yang bersifat teknis mendominasi jalannya sistem pengelolaan kegiatan usaha mikro. Sistem manajemen mulai diterapkan dalam komponen ini secara menyeluruh. Dimulai dari perencanaan produk, penerapan strategi pemasaran, pengelolaan keuangan, dan pengawasan terhadap kualitas produk. Manajemen adalah suatu rangkaian proses yang meliputi kegiatan perencanaan, pengorganisasian, pelaksanaan, pengawasan, evaluasi dan pengendalian dalam rangka memberdayakan seluruh sumber daya organisasi/ perusahaan, baik sumberdaya manusia (human resource capital), modal (financial capital), material (land, natural resources or raw materials), maupun teknologi secara optimal untuk mencapai tujuan organisasi/ perusahaan (Solihin, 2012). Menurut (Sisk, 1969), manajemen adalah peroses pengkoordinasian seluruh sumber daya melalui perencanaan, pengorganisasian, pengarahan dan pengendalian untuk mencapai tujuan yang telah ditetapkan. Sedangkan menurut George R. Terry, manajemen adalah suatu proses khas yang terdiri atas tindakan-tindakan perencanaan, pengorganisasian, penggerakan, dan pengendalian untuk menentukan serta mencapai tujuan melalui pemanfaatan SDM dan sumber daya lainnya (Athoillah, 2010). Dalam hal perencanaan produk, pelaku usaha mikro mulai merancang produk apa yang akan dibuat, segmentasi pasar mana yang akan dituju, berapa harga jual untuk produk, dan berapa keuntungan yang ingin diperoleh. Dalam hal strategi pemasaran, pelaku usaha mikro mulai menentukan promosi apa yang akan digunakan serta apakah akan dijual dengan menggunakan konsep tradisional dengan penjualan langsung atau konsep modern dengan menggunakan penjualan secara daring/online.

Berkaitan dengan pengelolaan keuangan, maka pelaku usaha mikro harus memiliki pembukuan yang baik walaupun sifatnya berupa pembukuan dengan catatan yang sederhana berupa catatan pemasukan dan pengeluaran serta untuk mencatat jumlah hutang dagang dan piutang dagang. Pembukuan sederhana ini juga berfungsi sebagai catatan modal berjalan yang digunakan serta sebagai pemisah terhadap uang yang digunakan untuk pemenuhan kebutuhan rumah tangga dari pelaku usaha mikro. Dalam hal pengawasan terhadap kualitas yang merupakan sebuah kegiatan penjaminan mutu yang harus dijaga dalam rangka memperoleh pembeli potensial dan menjaga kepuasan konsumen yang loyal terhadap produk yang dijual oleh pelaku usaha mikro. Menurut Robert J. Mockler menyatakan bahwa pengawasan manajemen adalah suatu usaha sistematik untuk menetapkan standart pelaksanaan dengan tujuan-tujuan perencanaan, merancang sistem informasi, umpan balik, membandingkan kegiatan nyata dengan standard yang telah ditetapkan sebelumnya, menentukan dan mengukur penyimpanganpenyimpangan serta mengambil tindakan koreksi yang diperlukan untuk menjamin bahwa semua sumber daya perusahaan dipergunakan dengan cara efektif dan efisien dalam pencapaian tujuan-tujuan perusahaan (Zamani, 1998).

Sedangkan menurut (Prayudi, 1981), Pengawasan adalah suatu proses untuk menetapkan pekerjaan apa yang dijalankan, dilaksanakan, atau diselenggarakan itu dengan apa yang dikehendaki, direncanakan atau diperhatikan. Pengawasan terhadap kualitas sering di abaikan oleh pelaku usaha mikro, dalam pandangan pelaku usaha 
mikro segala kegiatan produksi yang dilakukan merupakan kegiatan yang berulang, maka dalam hal ini tidak perlu adanya keraguan terhadap produk yang dihasilkan. Sejatinya pengawasan terhadap kualitas ini sangat penting yang dimulai dari pemilihan bahan baku, penggunaan dan peracikan bahan baku menjadi bahan jadi, serta cita rasa dari produk yang dihasilkan harus memiliki standar baku sesuai dengan standar yang ditetapkan secara pribadi oleh pelaku usaha mikro sampai dengan pengemasan produk yang dihasilkan serta pelayanan yang prima bagi konsumen.

Output merupakan komponen yang ketiga dalam sistem pengelolaan kegiatan usaha mikro. Dalam komponen output ini, pelaku usaha mikro menghasilkan produk yang akan dijual dan mekanisme pelayanan yang akan diberikan kepada kosumen. Unsur yang pertama yaitu unsur produk yang dihasilkan, pelaku usaha mikro harus mempertimbangkan tentang kualitas yang nyata yang dapat dirasakan langsung oleh konsumen terhadap produk yang dihasilkan. Berkaitan dengan hal ini, contohnya seperti cita rasa produk yang baik, produk yang higienis, serta kemasan produk yang menarik. Unsur yang kedua yaitu pelayanan, pelayanan merupakan unsur penyempurnaan terhadap produk yang dihasilkan oleh pelaku usaha mikro. Melalui pelayanan ini produk yang dihasilkan memiliki nilai tambah dan kesan yang akan dirasakan oleh konsumen.

Berkaitan dengan hal itu, produk dan pelayanan merupakan dua unsur yang memiliki sinergitas yang saling melengkapi dan menyempurnakan, produk yang dihasilkan walaupun memiliki kualitas yang baik namun jika diberikan dengan pelayanan yang buruk maka akan meninggalkan kesan negative bagi konsumen yang akan berakibat timbulnya sikap peralihan merek. Begitu juga sebaliknya, jika produk yang dihasilkan memiliki kualitas yang buruk namun pelayanan yang diberikan baik. Maka hal ini akan menimbulkan rasa tidak puas karena konsumen telah mengeluarkan biaya dalam rangka membeli produk, namun tidak memperoleh manfaat yang maksimal dari biaya yang sudah dikeluarkan. Dalam hal ini antara produk dan pelayanan harus mampu diberikan dengan baik yaitu produk yang berkualitas baik dan pelayanan yang prima agar menghasilkan kepusaan konsumen yang akan berdampak konsumen memiliki sikap loyal terhadap produk yang dihasikan oleh pelaku usaha mikro dan retensi terhadap produk yang dihasilkan oleh pesaing.

Pelaku usaha mikro saat ini dihadapkan dengan situasi yang menuntut produk yang dihasilkan harus dapat laku dipasaran, hal ini dibutuhkan adanya peningkatan kualitas pengelolaan manajemen. Peningkatan pengelolaan manajemen dapat dilakukan dengan adanya hard skill yang dimiliki oleh pelaku usaha mikro. Kita pahami bersama bahwa dilihat dari sisi hard skill, pelaku usaha mikro mayoritas hanya mengenyam pendidikan dasar. Hal ini akan menjadi sedikit rumit mengingat latar belakang pendidikan merupakan modal dasar yang dibutuhkan dalam pemahaman, pengembangan, dan peningkatan konsep manajemen. Dalam konsep pendidikan, keterbatasan atau ketidaktercapainya pendidikan formal dapat diganti dengan adanya pendidikan non formal. Seperti halnya ketidaktuntasan dalam pendidikan di Sekolah Menengah Atas dapat disetarakan dengan pendidikan Paket C. Namun, kita perlu 
pahami bersama bahwa pelaku usaha mikro dihadapkan pada situasi dimana mayoritas waktu yang digunakan adalah untuk melakukan kegiatan usaha dalam upaya memperoleh penghasilan. Peningkatan pemahaman bagi pelaku usaha mikro melalui mekanisme pendidikan non formal akan menyita banyak waktu dan mengganggu rutinitas kegiatan usaha yang dijalankan. Hal ini dinilai kurang efektive dan kurang dapat mencapai ketuntasan.

Dalam menyikapi hal ini, konsep pelatihan dirasa sangat tepat. Mengingat pelatihan dapat dilakukan dengan waktu yang relative singkat, misalnya dilakukan selama 2 hari dengan durasi pelatihan 8 jam tiap harinya. Pelatihan dasar tentang manajemen bagi pelaku usaha mikro ini akan sangat berguna bagi kelangsungan kegiatan usaha yang akan dijalankan maupun yang sedang dijalankan oleh pelaku usaha mikro. Melalui pelatihan dasar ini diharapkan pelaku usaha mikro memiliki pemahaman dan penerapan yang tepat tentang konsep manajemen. Pelaku usaha mikro akan memahami tentang bagaimana melakukan perencanaan, pengorganisasian, pengerahan, dan pengawasan terhadap kegiatan usaha yang dijalankan. Dengan adanya pelatihan dasar tentang manajemen maka hard skill dari pelaku usaha mikro akan mengalami peningkatan dan hal ini akan berdampak pelaku usaha mikro memiliki kesiapan yang lebih matang dalam menghadapi persaingan yang ketat di era sekarang ini. Hal ini juga akan berdampak positive dengan meningkatnya harapan akan semakin lamanya kegiatan usaha yang dijalankan dapat bertahan karena modal yang digunakan dikelola melalui mekanisme manajemen yang baik, serta pada akhirnya pelaku usaha mikro memiliki modal kerja yang stabil dan pendapatan yang dapat semakin ditingkatkan.

\section{Kesimpulan}

Usaha mikro merupakan sebuah alternative usaha ketika sempitnya peluang kerja yang tersedia di perusahaan serta menjadi alternative ketika modal yang dimiliki dalam jumlah yang terbatas. Modal yang terbatas yang dimiliki pelaku usaha mikro harus dapat dikelola dengan baik. Hal ini dimaksudkan agar usaha yang dijalankan dapat menghasilkan keuntungan sehingga kegiatan usaha dapat terus melakukan kegiatan operasionalnya dan tidak mengkikis modal yang ada. Berkaitan dengan hal itu, Perputaran modal merupakan faktor mendasar dari keberlangsungan kegiatan usaha yang dijalankan oleh pelaku usaha mikro atau dengan kata lain konsep perputaran modal ini sebagai bentuk pengembalian biaya produksi dan keuntungan yang diperoleh.

Pelaku usaha mikro mengenyam pendidikan pada tingkat pendidikan dasar. Perlu adanya pemahaman mendasar berkaitan dengan kemampuan teknis, dalam hal ini adalah hardskill yang berhubungan dengan pengetahuan yang dimiliki dalam pengelolaan sebuah kegiatan usaha, kemampuan menggunakan strategi pemasaran yang baik, kemampuan dalam mengelola arus kas maupun modal, kemampuan dalam pengelolaan bahan baku, serta kemampuan dalam pengembangan usaha. Dalam pelaksanaan kegiatan usaha mikro, hard skill belum diperhatikan oleh pelaku usaha mikro dalam menjalankan roda kegiatan usahanya. Hal ini sesungguhnya menjadi 
sebuah anomali antara ekistensi usaha yang harus dijalankan dengan implementasi dilapangan yang dilakukan.

Hard skill merupakan kompetensi yang mendasar yang harus dimiliki oleh pelaku usaha mikro. Hal ini karena melalui hard skill, konsep dari sebuah bisnis dapat dirancang dengan orientasi yang rasional dan menjadi dasar pengambilan keputusan tentang srategi pengelolaan yang akan digunakan serta melakukan evaluasi terhadap kegiatan usaha yang dilakukan. Konsep yang jelas tentang orientasi/tujuan kegiatan usaha menjadi penting karena dalam hal ini penentuan jenis produk yang akan dijual, harga yang akan ditetapkan, serta pasar mana yang hendak dijangkau memerlukan konsep yang jelas. Berkaitan dengan hal itu, orinetasi/tujuan kegiatan usaha yang rasional berarti bahwa orientasi kegiatan usaha berada dalam batasan-batasan yang dapat dijangkau oleh kemampuan dari pelaku usaha mikro itu sendiri. Selain itu juga, strategi pengelolaan kegiatan usaha bagi pelaku usaha mikro dapat efektive serta efisien melalui hard skill yang dimiliki. Kemudian melalui hard skill, ketepatan terhadap hasil evaluasi memiliki pengaruh terhadap perbaikan-perbaikan secara mendasar dalam konsep ketatalaksanaan kegiatan usaha mikro mulai dari perencanaan, pelaksanaan sampai ke tahap feedback yang diberikan oleh konsumen.

Konsep hard skill perlu dimiliki oleh pelaku usaha mikro sebagai suatu podasi dasar terhadap kegiatan usaha yang dijalankan. Hard skill yang merupakan pondasi dasar dalam sistem pengelolaan kegiatan usaha, melalui implementasi kedalam tiga komponen sistem pengelolaan usaha mikro. Komponen input ini berupa unsur modal usaha, ketersediaan bahan baku, dan sumber daya manusia. sedangkan komponen proses meliputi hal-hal bersifat teknis yang mendominasi jalannya sistem pengelolaan kegiatan usaha mikro dimana sistem manajemen mulai diterapkan dalam komponen ini secara menyeluruh. Dalam komponen output pelaku usaha mikro menghasilkan produk yang akan dijual dan mekanisme pelayanan yang akan diberikan kepada kosumen.

Dalam penelitian ini menghasilkan hipotesis bahwa sumber daya manusia melalui kompetensi hard skill memiliki pengaruh terhadap sistem kegiatan usaha mikro, hard skill merupakan pondasi dasar bagi pelaku usaha mikro dalam menjaga eksistensi kegiatan usaha, serta hard skill pelaku usaha mikro dapat ditingkatkan melalui pelatihan dasar manajemen. 


\section{BIBLIOGRAFI}

(ALMI), Akademi Ilmuan Muda Indonesia. (2019). Cek Fakta: Apakah Umkm Solusi Untuk Penciptaan Lapangan Pekerjaan? Retrieved April 4, 2019, from https://almi.or.id/2019/03/31/cek-fakta-apakah-umkm-solusi-untuk-penciptaanlapangan-pekerjaan/

Arikunto, Suharsimi. (2010). Prosedur penelitian. Rineka Cipta, Jakarta

Athoillah, Anton. (2010). Dasar-dasar manajemen. Pustaka Setia, Bandung.

Hendriana, Heris, Rohaeti, Euis Eti, \& Sumarmo, Utari. (2017). Hard skills dan soft skills matematik siswa. Refika Aditama, Bandung.

Hidayah, Dewi Meisari Haryanti dan Isniati. (2018). Potret UMKM Indonesia: Si Kecil yang Berperan Besar. Retrieved April 1, 2019, from https://www.ukmindonesia.id/baca-artikel/62

Mantja, Willem. (2003). Etnografi Desain Penelitian Kualitatif dan Manajemen Pendidikan. Winaka Media, Malang.

Prayudi. (1981). Hukum Administrasi Negara. Ghalia Indonesia, Jakarta.

Rasid, Zulkifli, Tewal, Bernhard, \& Kojo, Christoffel. (2018). Pengaruh Hard Skill dan Soft Skill Terhadap Kinerja Karyawan Perum Damri Manado. Jurnal EMBA: Jurnal Riset Ekonomi, Manajemen, Bisnis Dan Akuntansi, 6(2).

Sax, Gilbert. (1980). Princples of Education and Pshycological Measurement and Evaluation. Wods Worth Pub.Co, California, Belmont California.

Siagian, Ade Onny, \& Indra, Natal. (2019). Pengetahuan Akuntansi Pelaku Usaha Mikro Kecil dan Menengah (UMKM) Terhadap Laporan Keuangan. Syntax Literate; Jurnal Ilmiah Indonesia, 4(12), 17-35.

Sisk, Henry L. (1969). Principles Of Management. Philippine Copyright, Philippine, Cincinnati Ohio.

Solihin, Ismail. (2012). Pengantar Manajemen. Erlangga, Jakarta.

Sugiyono, Prof Dr. (2009). Metode Penelitian Kuantitatif Kualitatif Dan $R \& D$. Alfabeta, Bandung.

Sukardi. (2005). Metode Penelitian Pendidikan: Kompetensi dan Prakteknya. Bumi Aksara, Jakarta.

Sukardi. (2009). Evaluasi Pendidikan Prinsip dan Opeerasionalnya. PT. Bumi Aksaara, Jakarta. 
Kamaludin

Thoha, Miftah. (2008). Manajemen Sumber Daya Manusia . Raja Grafinda Jakarta PT, Jakarta.

Zamani, H. S. (1998). Manajemen. Badan Penerbit IPWI, Jakarta. 